\title{
PENGARUH KONSEP DIRI DAN MOTIVASI BERPRESTASI TERHADAP HASIL BELAJAR PESERTA DIDIK
}

\author{
Muhammad Amran Shidik ${ }^{1}$ \\ ${ }^{1}$ Univesitas Tmor, Kementerian Pendidikan dan Kebudayaan, Nusa Tenggara Timur \\ Imuh.amranshidik@gmail.com \\ https://doi.org/10.36052/andragogi.v8i2.177 \\ Diterima: 8 0ktober 2020 | Disetujui: 23 Desember 2020 | Dipublikasikan: 26 Desember 2020
}

\begin{abstract}
Abstrak
Tujuan yang diharapkan untuk dicapai dari penelitian ini adalah untuk mengetahui pengaruh dari konsep diri serta motivasi berprestasi terhadap hasil belajar peserta didik. Penelitian ini termasuk dalam penelitian kuantitatif dengan jenis penelitian ex post facto tipe causal research. Instrumen penelitian yang digunakan yaitu kuesioner tertutup untuk mengukur variabel konsep diri dan motivasi berprestasi serta tes dengan menggunakan pilihan ganda untuk mengukur hasil belajar peserta didik. Dalam penelitian ini yang menjadi sampel adalah peserta didik pada kelas XI IPA SMA Negeri 1 Kaledupa Kecamatan Kaledupa Kabupaten Wakatobi Provinsi Sulawesi Tenggara. Setelah data diperoleh, kemudian dianalisis dengan analisis regresi linier berganda dengan menggunakan aplikasi IBM SPSS 24. Berdasarkan hasil analisis data penelitian, diperoleh kesimpulan yaitu ada pengaruh konsep diri serta motivasi berprestasi terhadap hasil belajar peserta didik hal ini berdasarkan dari nilai signifikansi yang diperoleh sebesar $0,00<0,05$. Besarnya pengaruh konsep diri dan motivasi berpresatsi terhadap hasil belajar adalah $84,4 \%$, hal ini diperoleh berdasarkan dari nilai R Square setekah melakukan analisis data.
\end{abstract}

Kata Kunci: konsep diri, motivasi berprestasi, hasil belajar, peserta didik

\begin{abstract}
[THE EFFECT OF SELF-CONCEPT AND ACHIEVEMENT MOTIVATION ON STUDENTS 'LEARNING OUTCOMES]. The purpose of this research is to determine the effect of self-concept and achievement motivation on student learning outcomes. This research is included in quantitative research with the type of ex post facto causal research. The research instrument used was a closed questionnaire to measure the variables of self-concept and achievement motivation and a multiple choice test to measure student learning outcomes. The sample in this study were students of class XI IPA at SMA Negeri 1 Kaledupa, Kaledupa District, Wakatobi Regency, Southeast Sulawesi Province. After the data was obtained, it was analyzed with multiple linear regression analysis using the IBM SPSS 24 application. Based on the results of the research data analysis, it was concluded that there was an effect of self-concept and achievement motivation on student learning outcomes, this was based on the significance value obtained at $0.00<0.05$. The magnitude of the influence of self-concept and prestigious motivation on learning outcomes is $84.4 \%$, this is obtained based on the value of $R$ Square after data analysis.
\end{abstract}

Keywords: self-concept, achievement motivation, learning outcomes, students 


\section{PENDAHULUAN}

G uru merupakan salah satu tenaga profesional dengan tugas utama sebagai pendidik bagi peserta didiknya. Guru sejatinya tidak hanya menjadi media perantara untuk menyampaikan beberapa materi pelajaran. Selain menjadi perantara, guru juga bertindak sebagai fasilitator bagi peserta didiknya dalam pembelajaran. Guru membantu peserta didik untuk menumbuhkan kemauan dalam mengungkapkan pendapat maupun pikiran mereka dan menanggapinya secara positif. Peran guru dalam pembelajaran salah satunya adalah membimbing peserta didik sehingga mampu memahami serta mengeluarkan potensinya dengan baik, yang berarti seorang guru seharusnya bisa memberikan pandangan mengenai potensi serta apa kelemahan peserta didiknya, memotivasi peserta didik untuk menyampaikan isi pikirannya, membantu peserta didik untuk memiliki kepercayaan serta keberanian dalam mengambil keputusan (Manizar, 2015). Dengan kondisi ini, diharapkan kegiatan belajar mengajar menjadi aktif dan menyenangkan sehingga hasil belajar yang diperoleh memuaskan untuk kedua pihak baik guru maupun peserta didik.

Selain tugas-tugas yang sudah disebutkan sebelumnya, guru memiliki peran yaitu sebagai motivator kepada peserta didiknya. Motivasi merupakan suatu keadaan yang membuat individu tertentu untuk melakukan hal-hal yang diinginkan. Motivasi sendiri dapat muncul melalui diri seseorang itu sendiri atau luar diri sendiri. Motivasi memiliki peran yang cukup penting untuk peserta didik ketika aktivitas pembelajaran. Pada penelitian Esi et al (2016), peserta didik yang diberi motivasi berhasil mendapatkan hasil yang lebih baik dalam kegiatan belajar mengajar.

Ada banyak macam motivasi dalam diri setiap individu, salah satunya adalah motivasi untuk berprestasi. Selain motivasi untuk belajar, peserta didik harus memiliki motivasi berprestasi agar hasil yang diperolehnya lebih baik lagi. Peserta didik yang memiliki motivasi untuk berprestasi yang baik agar memiliki hasil belajar yang baik juga (Sahidin, 2013). Dengan memiliki motivasi untuk berprestasi pada diri peserta didik agar mampu bersaing pada setiap mata pelajaran yang diikuti, menampilkan jika sudah mulai memiliki kesadaran yang tinggi akan pentingnya belajar . Dalam penelitian (Sari \& Taman, 2013) dan (Trisnowali, 2017) motivasi berprestasi berpengaruh positif terhadap hasil belajar.

Faktor lainnya yang berpengaruh pada hasil belajar selain motivasi berprestasi adalah konsep diri. Konsep diri merupakan cara bagaimana seseorang memandang dan mempercayai dirinya sendiri. Konsep diri memiliki pengaruh yang positif untuk hasil belajar sorang peserta didik di mana semakin baik konsep diri mereka maka hasilnya pun baik pula (Alamsyah, 2016); (Rehanja, 2017); (Wiyani, 2017).

Lebih lanjut, konsep diri tidak pula hanya berimbas pada hasil belajar saja, akan tetapi mempengaruhi motivasi berprestasi peserta didik. Dalam penelitian Hartono (2015), diperoleh bahwa motivasi berprestasi dipengaruhi oleh konsep diri. Individu dengan kesan yang baik mengenai diri sendiri cenderung menampakkan perilaku yang positif. Kebalikan dari hal ini, seseorang yang memiliki persepsi kurang baik mengenai dirinya sendiri biasanya lebih sering menampakkan sikap tidak percaya diri dan tidak optimis mengenai suatu hal yang menjadi topik pembahasan. Kurang disiplinnya peserta didik dalam pembelajaran akan mempengaruhi hasil belajarnya sendiri, hal ini disebabkan oleh motivasi untuk berprestasi pada diri peserta didik belum tertanam dengan baik.

Berdasarkan hal-hal di atas, dilakukannya penelitian ini dengan tujuan agar mengetahui bagaimana pengaruh dari konsep diri serta motivasi berprestasi dalam pencapaian hasil belajar peserta didik. Peneliti melakukan penelitian ini sebab penelitian ini merupakan satu bagian penting dalam pendidikan bagi guru-guru untuk peserta didiknya. Pentingnya memberi motivasi kepada peserta didik serta membantu peserta didik mengkonsepkan diri peserta didik ke arah yang baik adalah bagian kecil yang tidak kalah penting dalam kegiatan pembelajaran.

Terlihat jelas dari sejumlah penelitian yang sebelumnya telah dilakukan dan telah diuraikan di atas, di mana motivasi berprestasi dan konsep diri merupakan bagian dari beberapa faktor yang berkontribusi bagi hasil belajar peserta didik. 
Sehingga dengan mengetahui motivasi berprestasi dan konsep diri peserta didiknya, guru dapat membantu dan mengerahkan peserta didiknya dengan baik. Dengan mengantongi konsep diri yang baik, seorang peserta didik akan mampu memiliki peluang dalam memahami dirinya dan kemampuan yang dimilikinya dalam setiap proses belajar mengajar berlangsung.

Penelitian mengenai pengaruh variabel motivasi berprestasi serta variabel konsep diri terhadap pencapaian hasil belajar ini, masih belum dilakukan dalam beberapa tahun terakhir di Kabupaten Wakatobi Provinsi Sulawesi Tenggara, khususnya di Kecamatan Kaledupa sendiri. Sehingga peneliti tertantang untuk menjalankan penelitian ini untuk mengetahui ada tidak pengaruh dari motivasi dalam berprestasi serta konsep diri berkenaan dengan pencapaian hasil belajar peserta didik di Kecamatan Kaledupa. Selain itu, penelitian ini dilaksanakan dengan tujuan agar mengetahui pengaruh dari konsep diri pada perolehan hasil belajar serta pengaruh motivasi dalam berprestasi atas hasil belajar. Penelitian ini juga dilakukan agar peneliti dan melihat apakah perolehan akhir penelitian serupa dengan penelitian lain yang sama yang dilakukan di daerah lainnya atau tidak. Dan juga sebagai sumbangsih kepada sekolah dan guru-guru di Kecamatan Kaledupa agar mengetahui seperti motivasi berprestasi dan konsep diri peserta didiknya dan bagaimana pengaruhnya untuk hasil belajar peserta didiknya.

\section{Konsep Diri}

Setiap individu memiliki konsep diri yang arahnya menuju fisik, social, emosional, dan intelektual (Weiten \& Lloyd, 2006). Konsep diri didefinisikan sebagai pandangan serta sikap seseorang terhadap kemampuan dirinya sendiri dan juga berperan penting ketika memastikan serta membimbing semua tingkah laku seseorang (Alamsyah, 2016). Konsep diri menjadi satu hal yang paling penting dalam model konsep, peran, perilaku, nilai, dan sikap yang disusun secara hierarkis. Tidak ada perubahan sikap mendasar yang bisa terjadi tanpa perubahan nilai, orientasi perilaku, peran yang harus dilakukan individu sebenarnya atau berpotensi, dan konsep diri individu terhadap dirinya sendiri.
Konsep diri seseorang merupakan produk dari hasil mempelajari dirinya (Subaryana, 2015). Sehingga konsep diri peserta didik menjadi sangat berpengaruh guna mengidentifikasi kapasitas dirinya, serta bagaimana cara mengelola persoalan yang sedang mereka dihadapi baik di lingkungan sekolah ataupun di luar lingkunagn sekolah. Dalam proses ini, individu mencoba untuk mendapatkan representasi yang jelas dan benar tentang dirinya sendiri, untuk memenuhi kebutuhan kognitifnya terhadap gambaran akan dirinya. Dengan demikian, konsep diri menjadi salah satu potongan berarti dalam perkembangan personalitas dan tidak menjadi bawaan sejak lahir. Konsep diri berkembang seiring dengan perkembangan kematangannya dalam memandang dirinya.

Persepsi tentang dirinya dapat berubah seiring waktu dan dengan pengetahuan serta pengalamannya. Pembentukan konsep diri terbagi ke dalam dua dimensi pokok, yang pertama dimensi internal yang terdiri atas self identity, behavioral self, dan judging self, serta yang kedua adalah dimensi eksternal yang terdiri atas moral-ethical self, family self, physical self, social self , dan personal self (Nida, 2014). Jadi konsep diri merupakan pandangan diri peserta didik terhadap kemampuan yang dimilikiya berdasrkan hasil dari pengalamannya yang dapat berubah seiring dengan bertambahnya pengetahuan dan pemahaman peserta didik tersebut.

\section{Motivasi Berprestasi}

Pada dasarnya setiap Tindakan yang dilakukan setiap orang disebabkan oleh dorongan dari faktor-faktor tertentu yang menjadikan hal tersebut perbuatan atau tingkah laku. Dorongan yang dimaksud biasanya disebut sebagai motif atau biasanya dikenal dengan motivasi. Motivasi adalah segala kemampuan penggerak yang ada pada diri seseorang yang menjamin kesinambungan, membangkitkan serta membagikan maksud dari aktivitas belajar, sehingga maksud yang diharapkan bisa dicapai (Uno, 2012). Dalam pentas edukasi, motivasi mengantongi kontribusi yang tidak kalah penting untuk mendapatkan hasil belajar yang diharapkan, dalam hal ini motivasi dalam berprestasi menjadi salah satunya. Menurut 
Hilgard (1983) motivasi berprestasi didefinisikan sebagai motif sosial dalam menjalankan seuatu yang dianggap penting atau berharga dengan baik serta sempurna agar mencukupi penunjang keunggulan dari apa yang dilakukan setiap orang.

McClelland (1987) dan Atkinson \& Feather (1966), menyatakan bahwa "agar mendapatkan prestasi, afiliasi, dan pengaruh, setiap individu harus memiliki motivasi untuk bertindak dan menginvestasikan energi". Rendahnya hasil belajar peserta didik, bisa diakibatkan oleh kurangnya motivasi berprestasi dari peserta didik itu sendiri. Dengan memiliki motivasi berprestasi, peserta didik akan merasa bahwa ia ingin mencapai hasil yang lebih lagi dari yang ia peroleh sebelumnya serta akan mampu mempertanggungjawabkan hasil yang telah ia peroleh melalui tugas yang diberikan. Menurut Martianah (1984) motivasi dalam berprestasi adalah suatu reaksi mental yang memiliki citacita serta maksud agar berhasil menjadi skala terbaik. Sebagai reaksi mental, dorongan dalam berprestasi juga diakibatkan oleh dua aspek yaitu yang pertama adalah aspek individu dan yang kedua adalah aspek lingkungan. Aspek yang berasal dari individu sendiri sering disebut sebagai faktor internal di mana sering dipengaruhi oleh aspek fisiologis, dan aspek psikologis peserta didik. Sedangkan aspek luar atau sering disebut dengan faktor eksternal biasanya dipengaruhi oleh faktor-faktor berikut: Faktor sosial (orang tua, guru, teman sebaya, lingkungan belajar) dan faktor non-sosial (sarana belajar dan kondisi lingkungan) (Suryabrata, 2002). Berdasarkan teori-teori yang telah dijelaskan sebelumnya maka dapat disimpulkan bahwa motivasi berprestasi adalah dorongan yang dialami oleh peserta didik untuk bersaing dengan peserta didik lainnya dalam memperoleh prestasi yang lebih baik.

\section{Hasil Belajar}

Usaha yang kerjakan agar mendapatkan suatu transformasi tingkah laku ke arah yang baik selaku produk dari pengetahuan sendiri ketika terjadi hubungan dengan suatu lingkungan disebut sebagai belajar (Slameto, 2010). Dari definisi ini, hasil belajar boleh dikatakan seperti peralihan perangai yang berlangsung pada peserta didik, yang diperoleh melalui pengamatan serta pengukuran mengenai transformasi pengetahuan, keterampilan, serta sikap mereka. Perubahan ini bisa dikatakan terjadi dengan adanya penambahan dan perkembangan menjadi lebih baik dari sebelumnya, seperti dari tidak mengetahui menjadi mengetahui, sikap tidak sopan menjadi sopan dan masih banyak hal lainnya.

Hasil belajar didefinisikan sebagai perolehan dari kegiatan belajar. Tiga unsur penting dalam proses pembelajaran terdiri atas: tujuan pengajaran, keahlian belajar mengajar serta hasil belajar (Sudjana, 2009). Sama halnya dengan definisi sebelumnya, menurut Purwanto (2009) "hasil belajar menggambarkan transisi yang membangkitkan individu untuk bertransformasi dalam tindak-tanduk serta sikapnya". Dimensi transformasi itu mengarah kepada tingkatan tujuan proses belajar mengajar yang buat oleh Bloom, Simpson dan Harrow yang terdiri atas aspek kognitif, psikomotorik, dan afektif. Sejalan dengan itu, Faturrahman (2016), menyatakan bahwa "pada kenyataannya perolehan dari sebagian kompetensi yang meliputi aspek keterampilan, sikap, dan pengetahuan serta poin-poin yang dibentuk dalam rutinitas bertindak serta berpikir disebut juga sebagai hasil belajar fisika".

Seringkali hasil belajar dijadikan sebagai tolak ukur dalam menyelami seberapa jauh peserta didik mengendalikan bahan yang telah dipelajari. Dalam hal mendapatkan hasil belajar tertentu, dibutuhkan beberapa alur penilaian yang memanfaatkan instrumen evaluasi yang tepat serta memenuhi syarat. Penilaian seperti ini di mungkinkan sebab penilaian menggambarkan aktivitas ilmiah yang bisa dilakukan dalam berbagai macam bidang seperti pendidikan (Purwanto, 2009).

Hasil belajar terpecah ke dalam tiga bidang yaitu bidang kognitif, bidang afektif, dan bidang psikomotorik (Sudjana, 2009). Dalam penelitian kali ini, yang menjadi tinjauan utama adalah hasil belajar pada bidang kognitif peserta didik. Bidang kognitif biasanya berkenaan dengan hasil intelegensi peserta didik. (Anderson \& Krathwohl, 2001) sudah melaksanakan peninjauan Kembali tingkatan pada aspek kognitif Bloom sehingga menjadi sebagai berikut: mengingat, memahami, menerapkan, menganalisis, mengevaluasi, dan menciptakan. 
Aspek-aspek yang mempengaruhi hasil belajar antara lain adalah aspek eksternal (yang bersumber dari luar diri peserta didik) dan aspek internal (yang bersumber dari dalam diri peserta didik) (Dimyati \& Mudjiono, 2013).

Hasil belajar peserta didik merupakan capaian atau perolehan peserta didik akibat upaya atau solusi yang telah dituangkan kedalam bentuk kemapuan, kompetensi dan kapabilitas dasar yang ada dalam aspek-aspek kehidupan.

\section{METODE PENELITIAN}

Penelitian menggambarkan penelitian kuantitatif dengan tipe penelitian dipakai yaitu penelitian ex post facto dengan jenis Causal researh. Dalam penelitian ini metode yang digunakan menunjukkan jika perlakuan kepada variabel bebas sudah terjadi sebelumnya, oleh karena itu tidak perlu lagi diberi perlakuan, dan cukup melihat pengaruhnya ke variabel terikat. Penelitian ini dilaksanakan di SMA Negri 1 Kaledupa Kecamatan Kaledupa Kabupaten Wakatobi Sulawesi Tenggara.

Dalam penelitian terdapat dua variabel yakni variabel bebas serta terikat. Variabel bebas terbagi menjadi dua yaitu konsep diri (X1) serta motivasi berprestasi $(X 2)$. Sedangkan variabel terikatnya adalah hasil belajar (Y). Desain penelitian ini dapat dilihat pada gambar 1 berikut:

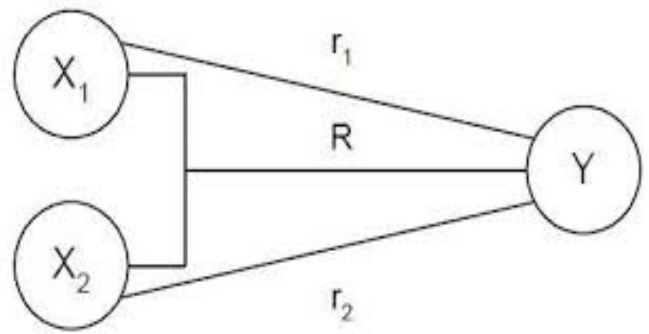

Gambar 1. Desain Penelitian

Pada gambar 1 dapat dilihat arah dari garis-garis tersebut, di mana $r_{1}$ merupakan pengaruh dari variabel konsep diri terhadap hasil belajar, $r_{2}$ merupakan pengaruh motivasi berprestasi terhadap hasil belajar, sedangkan $\mathrm{R}$ merupakan pengaruh konsep diri serta motivasi berprestasi terhadap hasil belajar.

Populasi yang digunakan dalam penelitian yaitu segenap peserta didik pada SMA Negeri 1 Kaledupa Kecamatan Kaledupa. Sedangkan sampel penelitian adalah peserta didik kelas XI pada jurusan (Ilmu Pengetahuan Alam) IPA dengan jumlah 75 peserta didik. Cara perolehan sampel untuk penelitian ini digunakan purposive sampling. Purposive sampling artinya pengambilan sampel yang dilakukan oleh peneliti dengan mempertimbangkan hal-hal tertentu (Sugiyono, 2015). Setelah sampel diperoleh kemudian dilakukan pengumpulan data oleh peneliti.

Data pada penelitian ini dikumpulkan dengan menggunakan dua macam instrumen, yaitu instrumen non-tes serta instrumen tes. Instrumen non-tes yang digunakan adalah kuesioner tertutup untuk mengetahui konsep diri dan motivasi peserta didik dan instrumen tes digunakan pilihan ganda untuk mengetahui hasil belajar peserta didik. Kuesioner digunakan untuk memperoleh data variabel konsep diri serta motivasi dalam berprestasi, sedangkan tes dimanfaatkan untuk memperoleh data hasil belajar peserta didik. Untuk kuesioner konsep diri, terdiri dari 27 pertanyataan dengan 22 pernyataan positif dan 5 pertanyaan negatif dengan 5 pilihan jawaban yaitu Sangat tidak sesuai (STS), Tidak Sesuai (TS), Kurang sesuai (KS), Sesuai (S), dan Sangat sesuai (SS). Sedangkan untuk kuesioner motivasi berprestasi terdiri dari 38 pernyataan, 32 diantaranya adalah pernyataan positif sedangkan 6 sisanya adalah pernyataan negatif. Pilihan jawaban pada kuesioner ini sama seperti yang ada pada kuesioner konsep diri yang terdiri dari 5 pilihan jawaban. Untuk skor setiap butir pertanyaan pada kuesioner untuk pertanyaan positif dari Sangat Sesuai (SS) sampai dengan Sangat Tidak Sesuai (STS) berturut-turut adalah 5 sampai dengan 1. Sedangkan untuk butir pertanyaan negatif dari Sangat Sesuai (SS) sampai dengan Sangat Tidak Sesuai (STS) berturut-turut adalah 1 sampai dengan 5 . Tes hasil belajar dibuat dengan format pilihan ganda yang jumlah butir soalnya 33 butir soal dengan 5 pilihan jawaban.

Instrumen yang digunakan telah divalidasi terlebih dahulu oleh 2 pakar, selanjutnya diujicobakan dan dilakukan analisis butir dari tiap variabel. Dari hasil analisis butir ini diperoleh untuk variabel konsep diri dari 31 butir pertanyaan terdapat 27 butir pertanyaan yang valid dan 4 lainnya tidak valid serta nilai reliabilitasnnya adalah 0,8 . Untuk variabel 
motivasi berprestasi jumlah butir yang valid dari 42 adalah 38 butir dengan nilai reliabilitas 0,92. Serta untuk variabel hasil belajar diperoleh jumlah butir soal yang valid 33 butir dari 44 butir soal yang disiapkan dengan nilai reliabilitas sebesar 0,93.

Data yang didapatkan selanjutnya dianalisis menggunakan teknik analisis regersi linier berganda. Untuk memudahkan dalam menganalisis data, peneliti memanfaatkan bantuan aplikasi IBM SPSS Statistics 24. Sebelum melakukan analisis ini, peneliti terlebih dahulu melakukan uji prasyarat statistik parametrik di mana dalam uji ini ada tiga asumsi yang harus dipenuhi yaitu uji normalitas dan memenuhi asumsi klasik lainnya yaitu bebas dari asumsi multikolinieritas, dan heteroskedastisitas.

\section{TEMUAN DAN PEMBAHASAN}

\section{Temuan}

Setelah membagikan kuesioner motivasi berprestasi dan tes pilihan ganda hasil belajar kepada peserta didik, peneliti kemudian melakukan input data kedalam aplikasi IBM SPSS Statistics 24 dan diperoleh data penelitian yang dapat dilihat pada tabel 1 mengenai deskripsi perolehan data penelitian:

Tabel 1. Deskripsi Perolehan Data Penelitian

\begin{tabular}{lc|r|r|r|r|c}
\hline & N & Min & \multicolumn{1}{c|}{ Max } & Jumlah & Rerata & Sd \\
\hline Konsep Diri & 75 & 70 & 99 & 6260 & 83.47 & 7.098 \\
\hline Motivasi & 75 & 112 & 140 & 9262 & 123.49 & 8.054 \\
\hline Hasil Belajar & 75 & 16 & 23 & 1408 & 18.77 & 1.752 \\
\hline Valid N & 75 & & & & & \\
\hline
\end{tabular}

Pada tabel 1 dapat dilihat dari 75 peserta didik yang menjadi sampel, skor rata-rata konsep diri peserta didik adalah 83,47 perolehan skor terendah yaitu 70 serta skor tertinggi yaitu 99 . Rerata skor motivasi berprestasi peserta didik adalah 123,49

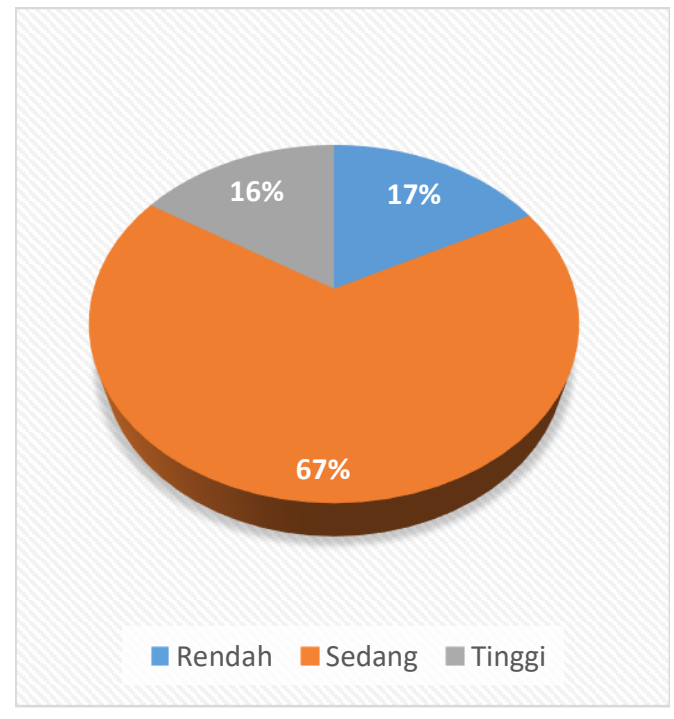

Gambar 2. Persentasi Kategori Konsep Diri Peserta
Pada gambar 2, dapat dilihat gambaran kategori skor pada variabel konsep diri peserta didik dari 75 orang 13 orang memiliki konsep diri rendah (17,3\%), 50 orang $(66,7 \%)$ memiliki konsep diri pada kategori sedang, dan 12 orang (16\%) memiliki konsep diri pada kategori tinggi. Dengan demikian rata-rata konsep diri peserta didik berada pada kategori sedang.

Skor motivasi berprestasi peserta didik dari 75 orang 19 orang memiliki konsep diri rendah $(25,3 \%), 43$ orang $(57,3 \%)$ memiliki konsep diri pada kategori sedang, dan 13 orang $(17,4 \%)$ memiliki konsep diri pada kategori tinggi. Dengan demikian rata-rata motivasi berprestasi peserta didik berada pada kategori sedang. Gambaran data motivasi berprestasi ini dapat dilihat pada gambar 3 


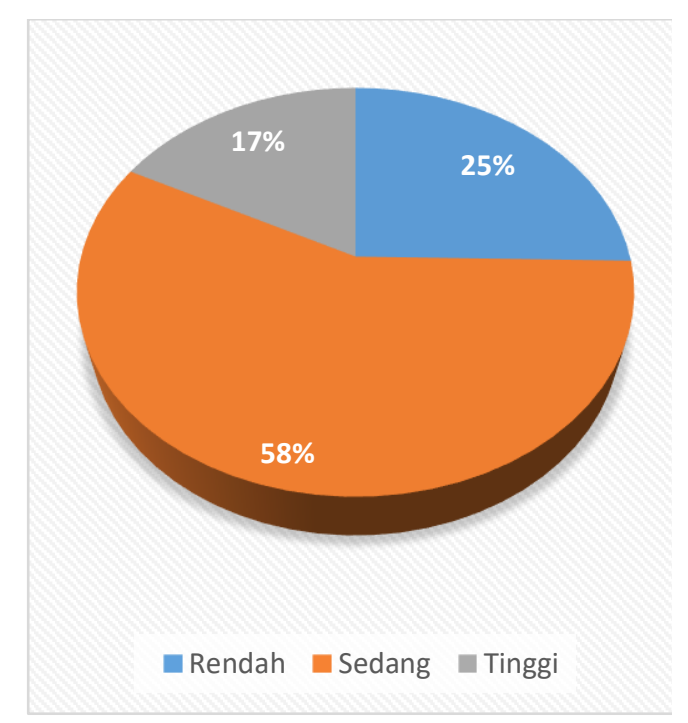

Gambar 3. Persentasi Kategori Motivasi Berprestasi Peserta Didik

Selanjutnya skor hasil belajar peserta didik dari 75 orang terdapat 28 orang $(37,3 \%)$ memiliki hasil belajar kategori rendah, 35 orang $(46,7 \%)$ memiliki hasil belajar kategori sedang, dan 12 orang (16\%) memiliki hasil belajar kategori tinggi. Jadi rata-rata hasil belajar peserta didik berada pada kategori sedang. Untuk lebih jelasnya perhatikan gambar 4 .

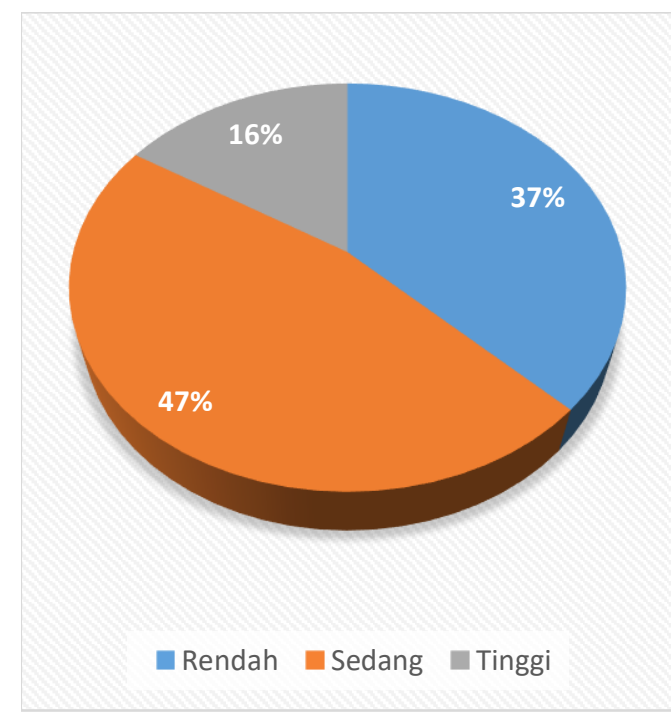

Gambar 4. Persentasi Kategori Hasil Belajar Peserta Didik
Data yang diperoleh kemudian dianalisis menggunakan analisis regresi linier berganda. Namun sebelum itu, data yang diperoleh harus harus berdistribusi normal dan memenuhi asumsi-asumsi yang telah dijabarkan dalam metode penelitian sebelumnya. Asumsi-asumsi yang dimaksud terdiri dari tidak ada gejala multikolinearitas, dan tidak terjadi gejala heteroskedastisitas.

Pada uji normalitas data, dilakukan dengan menggunakan uji normalitas probabiliti plot. Dalam model regresi, data dikatakan berdistribusi normal apabila data ploting (bulatan kecil) yang melukiskan data sebenarnya menyusuri garis lurus (Ghozali, 2016). Perolehan uji normalitas bisa dilihat pada gambar 5. Bersumber pada gambar 5, dapat dilihat jika titik-titik atau data ploting pada gambar terlihat mengikuti garis diagonal yang ada. Artinya data yang diperoleh berdistribusi normal 


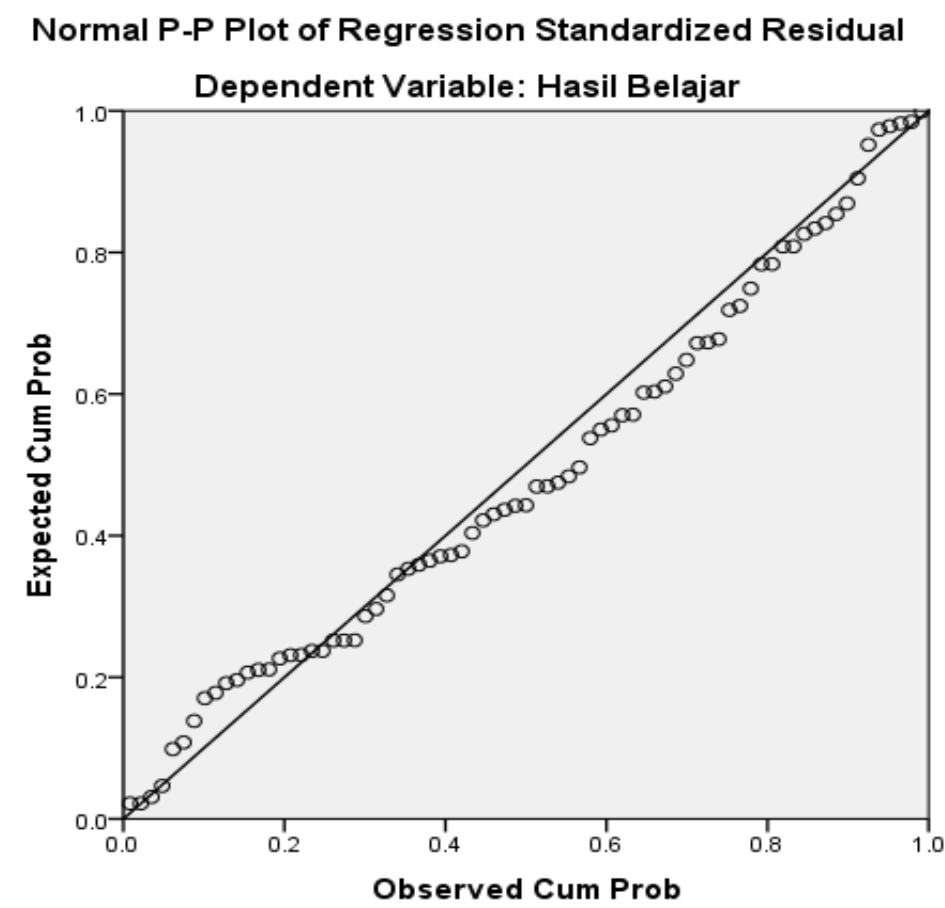

Gambar 5. Hasil Uji Normalitas Probabiliti Plot

Setelah data diketahui berdistribusi normal, selanjutnya dilakukan uji asumsi multikolinearitas dengan metode tolerance dan VIF. Dengan asumsi tidak ada gejala multikolinearitas apabila nilai tolerance $>0.100$ dan nilai VIF < 10,00 (Ghozali, 2016).

Hasil uji multikoleniaritas data terdapat pada pada table 2 beriktu:

Tabel 2. Hasil Uji Multikolinearitas dengan Metode Tolerance dan VIF

\begin{tabular}{llr|r|r|r|}
\hline \multirow{2}{*}{ Model } & \multicolumn{2}{c|}{$\begin{array}{c}\text { Unstandardized } \\
\text { Coefficients }\end{array}$} & \multicolumn{2}{c}{$\begin{array}{c}\text { Collinearity } \\
\text { Statistics }\end{array}$} \\
\cline { 3 - 7 } & & \multicolumn{1}{c}{ B } & \multicolumn{1}{c|}{ Std. Error } & \multicolumn{1}{c}{ Tolerance } & \multicolumn{1}{c}{ VIF } \\
\hline 1 & 1.185 & 2.271 & & \\
\cline { 2 - 7 } & (Constant) & .085 & .038 & .297 & 3.369 \\
\cline { 2 - 7 } & Konsep Diri & .085 & .033 & .297 & 3.369 \\
\cline { 2 - 7 } & Motivasi & & & & \\
\hline
\end{tabular}

Berdasarkan tabel 2, diperoleh bahwa nilai tolerance untuk variabel konsep diri serta motivasi berprestasi sebesar $0,297>0,100$ dengan nilai VIF $3,369<10,00$. Berdasarkan data ini maka diperoleh hasil uji bahwa tidak terjadi gejala multikoleniaritas.

Asumsi selanjutnya adalah uji hetereoskedastisitas dengan menggunakan uji glejser. Tujuan utama dari uji asumsi ini yaitu untuk mengetahui ada atau tidaknya kesamaan varian dari nilai residual untuk semua variabel pengamatan. Asumsi dalam uji ini adalah tidak terjadi gelaja heteroskedastisitas apabila nilai siginifikansi atau Sig $>0,05$. 
Tabel 3. Hasil Uji Heteroskedastisitas dengan Metode Glejser

\begin{tabular}{|c|c|c|c|c|c|}
\hline & \multirow[t]{2}{*}{ Model } & \multicolumn{2}{|c|}{$\begin{array}{l}\text { Unstandardized } \\
\text { Coefficients }\end{array}$} & \multirow{2}{*}{$\begin{array}{c}\text { Std } \\
\text { Coefficients } \\
\text { Beta } \\
\end{array}$} & \multirow[t]{2}{*}{ Sig. } \\
\hline & & B & Std. Error & & \\
\hline \multirow{3}{*}{1} & (Constant) & -.992 & 1.434 & & .491 \\
\hline & Konsep Diri & -.010 & .024 & -.089 & .679 \\
\hline & Motivasi & .022 & .021 & .227 & .291 \\
\hline
\end{tabular}

a. Dependent Variabel: Abs_Res

Pada tabel 3 menunjukan hasil uji asumsi heteroskedastisitas tiap variabel $X$ terhadap hasil belajar (Y). Dari tabel 3, diperoleh nilai signifikansi untuk variabel konsep diri adalah $0,679>0,05$ dan untuk variabel motivasi sebesar 0,291 . Nilai signifikansi kedua variabel lebih besar dari 0,05, hal ini menandakan bahwa berdasarkan analisis diasumsikan bahwa tidak terjadi gejala heteroskedastisitas.

Dari hasil uji prasyarat yang telah dilakukan, ketiga asumsi telah terpenuhi di mana data berdistribusi normal, tidak memiliki gejala multikolinieritas, serta tidak mempunyai gejala heteroskedastisditas. Setelah asumsi-asumsi ini terpenuhi, maka dapat dilanjutkan dengan melakukan analisis regresi linier berganda. Diperoleh hasil analisis sesuai tabel 4 dan 5 . Uji t parsial artinya adalah menguji pengaruh dari tiap variabel $X$ terhadap variabel $Y$. Dalam hal ini, pengaruh yang dimaksud adalah konsep diri (X1) terhadap hasil belajar ( $Y$ ) dan motivasi berprestasi (X2) terhadap (Y). Untuk mengetahui $r_{1}$ dan $r_{2}$ seperti pada desain penelitian, maka dilakukan uji t parsial. Pada tabel 5 dapat dilihat bahwa nilai signifikansi pada variabel konsep diri adalah 0,029 $<0.05$. Yang berarti ada pengaruh konsep diri terhadap hasil belajar. Kemudian nilai signifikansi untuk variabel motivasi berprestasi sebesar 0,013 < 0,05 . Artinya ada pengaruh motivasi belajar terhadap hasil belajar peserta didik. Berdasarkan hasil uji t parsial ini, dapat dikatakan bahwa setiap variabel $X$ memberikan pengaruh positif terhadap variabel $Y$. Variabel konsep diri (X1) berpengaruh positif terhadap hasil belajar $(Y)$ dan variable motivasi berprestasi berpengaruh positif terhadap hasil belajar peserta $\operatorname{didik}(\mathrm{Y})$.

Tabel 4. Hasil Uji t Parsial

\begin{tabular}{|c|c|c|c|c|c|c|}
\hline \multirow{2}{*}{\multicolumn{2}{|c|}{ Model }} & \multicolumn{2}{|c|}{$\begin{array}{l}\text { Unstandardized } \\
\text { Coefficients }\end{array}$} & \multirow{3}{*}{$\begin{array}{c}\text { Standardized } \\
\text { Coefficients } \\
\text { Beta } \\
\end{array}$} & \multirow{3}{*}{$\begin{array}{l}\mathbf{t} \\
.522 \\
\end{array}$} & \multirow{3}{*}{$\begin{array}{l}\text { Sig. } \\
.603 \\
\end{array}$} \\
\hline & & \multirow{2}{*}{$\begin{array}{l}\text { B } \\
1.185\end{array}$} & \multirow{2}{*}{$\begin{array}{r}\text { Std. Error } \\
2.271\end{array}$} & & & \\
\hline 1 & (Constant) & & & & & \\
\hline & Konsep Diri & .085 & .038 & .343 & 2.234 & .029 \\
\hline & Motivasi & .085 & .033 & .392 & 2.552 & .013 \\
\hline
\end{tabular}

Tabel 5. Hasil Uji F Simultaan

\begin{tabular}{rr|r|r|c|c}
\hline Model & Sum of Squares & df & Mean Square & F & Sig. \\
\hline Regression & 112.755 & 2 & 56.377 & 35.485 & $.000^{\mathrm{b}}$ \\
\hline
\end{tabular}

Setelah uji parsial, dilakukanuji $\mathrm{F}$ simultan untuk mengetahui $R$ seperti pada gambar 1 desain penelitian ini. Untuk uji $F$ simultan, dapat dilihat pada tabel 5. Tujuan dari uji $F$ simultan adalah untuk mengetahui pengaruh dari kedua variabel $X$ yaitu konsep diri serta motivasi berprestasi terhadap variabel $Y$ atau hasil belajar. Berdasarkan tabel 5 , diperoleh nilai sig. sebesar $0,00<0,05$. Sehingga dapat dikatakan bahwa konsep diri (X1) dan motivasi berprestasi $(\mathrm{X} 2)$ berpengaruh terhadap hasil belajar peserta $\operatorname{didik}(\mathrm{Y})$.

Langkah selanjutnya yaitu melihat seberapa besar persentasi pengaruh yang 
diberikan oleh variabel konsep diri dan motivasi berprestasi secara simultan terhadap variabell hasil belajar. Untuk mengetahui hal tersebut, maka perlu diketahui nilai $R$ Square dari hasil analisis. Pada table 6 , diketahui nilai $R$ Square diperoleh sebesar 0,844 . Ini menunjukkan besarnya koefisien determinasi ( $R$ Square) yaitu
0,844 atau sama halnya dengan $84,4 \%$. Artinya, variabel konsep diri dan motivasi berprestasi secara bersama-sama mempengaruhi variabel hasil belajar sebesar $84,4 \%$. Sedangkan sisa dari ini $15,6 \%$ dipengaruhi oleh variabl lainnya diluar variabel yang diteliti.

Tabel 6. Nilai R Square

\begin{tabular}{ll|r|r|r}
\hline Model & R & R Square & $\begin{array}{c}\text { Adjusted R } \\
\text { Square }\end{array}$ & $\begin{array}{c}\text { Std. Error of } \\
\text { the Estimate }\end{array}$ \\
\hline 1 & $.919^{\mathrm{a}}$ & .844 & .840 & .701 \\
\hline
\end{tabular}

\section{Pembahasan}

\section{Pengaruh Konsep Diri Terhadap Hasil Belajar Peserta Didik}

Hasil penelitian ini menemukan bahwa konsep diri berpengaruh positif terhadap hasil belajar peserta didik. Sejalan dengan penelitian yang dilakukan oleh Rosa (2015) dan Tiorenna (2015) yang memperoleh kesimpulan bahwa ada pengaruh konsep diri terhadap hasil belajar peserta didik. Konsep diri adalah pandangan peserta didik seperti kepercayaan akan kelebihan dan kekurangan yang dimiliki dirinya dan berperan sebagai pendorong dalam melakukan usaha untuk peningkatan prestasi belajar (Alamsyah, 2016). Pendapat lainnya dari (Andinny, 2015), konsep diri merupakan pandangan, pemikiran dan penilaian individu terhadap dirinya sendiri setelah memperoleh pengetahuan baik melalui proses pembelajaran maupun melalui pengalaman hidup setiap hari yang individu tersebut peroleh dari lingkungannya. Berdasarkan beberapa definisi sebelumnya, maka dapat disimpulkan bahwa konsep diri merupakan pandangan seorang peserta didik terhadap dirinya sendiri dalam melakukan suatu tindakan untuk mendorong tindakan tersebut sesuai dengan caranya dan kemampuan yang ia miliki.

Konsep diri dalam pembelajaran sangatlah penting. Peserta didik yang mempunyai konsep diri yang baik lebih condong mendapatkan hasil belajar yang baik pula. Sejalan dengan pendapat dari (Rosa, 2015) bahwa "peserta didik dengan konsepsi diri tinggi bisanya memiliki kepercayaan diri untuk menggali potensi yang ada dalam dirinya sehingga dapat berpengaruh pada perolehan prestasi yang tinggi, sebaliknya peserta didik dengan konsep diri rendah akan mengalami hambatan dalam pembelajaran yang akan berpengaruh pada prestasi belajar. Peserta didik yang mempunyai konsep diri yang tinggi biasanya memiliki motivasi yang tinggi pula dalam kegiatan pembelajaran. Hal ini dikarenakan peserta didik dengan konsep diri yang tinggi akan lebih aktif dalam kelas disebabkan oleh kemampuan mereka dalam memahami kemampuannya sindir dalam menilai situasi dan masalahmasalah yang diberikan.

Peserta didik dengan konsep diri yang tinggi cenderung tidak akan cemas serta mampu mengatasi hambatan dalam proses pembelajaran sehingga mendukung pencapaian hasil belajar yang tinggi pula (Alamsyah, 2016). Untuk memperoleh hasil belajar yang baik, seharusnya peserta didik memiliki kemauan yang kuat dan besar juga untuk meraihnya, sehingga peserta didik harus mengkonsepkan dirinya sebaik mungkin agar dapat meningkatkan kepercayaan dirinya untuk meraih hasil belajar yang baik. Dengan konsep diri yang baik peserta didik akan memiliki keinginan dan kemampuan dalam memahami situasi dan masalah-masalah yang diberikan Ketika dalam proses belajar mengajar.

\section{Pengaruh Motivasi Berprestasi Terhadap Hasil Belajar Peserta Didik}

Berdasarkan hasil analisis uji t parsial, untuk pengaruh motivasi berprestasi terhadap hasil belajar, diperoleh kesimpulan terdapat pengaruh positif motivasi berprestasi terhadap hasil belajar fisika peserta didik. Hal ini sejalan dengan penelitian yang dilakukan oleh (Nur \& Massang, 2016) yang mengatakan bahwa terdapat pengaruh motivasi berprestasi 
berkenaan dengan hasil belajar peserta didik. Selain itu, dalam penelitian (Dwija, 2008), memberi isyarat jika "motivasi dalam berprestasi menyimpan kekerabatan yang kuat dengan hasil belajar peserta didik". Dari beberapa pendapat sebelumnya, dapat dikatakan bahwa motivasi berprestasi bisa menjadi salah satu komponen yang mempengaruhi hasil belajar peserta didik.

Motivasi pada diri setiap orang merupakan kemauan dasar yang menjadi dorongan kepada orang tersebut tersebut untuk mencapai berbagai pemenuhan segala kebutuhan dirinya (Manizar, 2015). Kondisi psikologis dan fisiologis yang terdapat di dalam diri seseorang yang membuatnya terdorong untuk melakukan kegiatan tertentu demi mencapai tujuan tertentu setinggi mungkin disebut motivasi berprestasi (Sudia \& Majja, 2016). Senada dengan pemikiran di atas, menurut (Winkel, 2014) "achievement motivation menjadi pengambil inisiatif dalam diri individu untuk mendapatkan tingkatan prestasi yang lebih tinggi dan penghargaan diri sendiri". Dari beberapa pendapat di atas dapat diketahui bahwa motivasi berpresatsi adalah dorongan atau penggerak dari dalam diri setiap peserta didik untuk mencapai hasil yang baik dalam mencapai tujuan tertentu.

Peserta didik dengan motivasi berprestasi tinggi condong lebih cepat dalam hal menyelesaikan tugasnya dibandingkan dengan peserta didik yang memiliki motivasi berprestasi rendah. Peserta didik dengan motivasi berprestasi tinggi memiliki hasil belajar yang lebih tinggi dibandingkan dengan peserta didik yang memiliki motivasi berprestasi rendah, hal ini disebabkan oleh peserta didik dengan motivasi berprestasi tinggi memiliki keinginan untuk menyelesaikan tugas dengan hasil yang baik (Herlina, 2016).

Motivasi berprestasi peserta didik bisa dibangkitkan dengan kiat menyampaikan stimulus yang arahnya pada apa yang dibutuhkan peserta didik (Trisnowali, 2017). Peserta didik yang mempunyai motivasi selalu ingin unggul serta berprestasi Ketika berlangsung kegiatan pembelajaran dan tidak merasa takut untuk tidak berhasil tetapi selalu berusaha untuk memperbaiki kesalahan yang ia dapat sehingga dapat meningkatkan hasil belajar fisikanya. Motivasi berprestasi dapat diperoleh melalui guru-guru sebagai motivator ataupun dari diri peserta didik sendiri, dalam hal ini peserta didik memotivasi diri sendiri untuk meraih prestasi yang baik dalam pembelajaran.

\section{Pengaruh Konsep diri serta motivasi berprestasi Terhadap Hasil Belajar Peserta Didik}

Hasil analisis data penelitian pada bagian ini dapa dilihat pada tabel 6 uji F simultan. Diperoleh bahwa, secara simultan terdapat pengaruh motivasi berprestasi serta konsep diri terhadap perolehan hasil belajar. Penelitian ini memiliki hasil yang sejalan dengan penelitian yang telah dilakukan oleh (Tiorenna, 2015), (Sahidin, 2013), dan (Nur, 2016).

Hasil belajar fisika dipengaruhi oleh faktorfaktor kognitif, psikomotor, dan afektif. Dalam hal ini adalah konsep diri dan motivasi berprestasi. Konsep diri merupakan persepsi diri peserta didik terhadap diri sendiri tentang simbol-simbol pribadi serta berbagai peran yang dilakukan seseorang (Yapono, 2013). Konsep diri memiliki peranan yang penting dalam kegiatan pembelajaran. Oleh sebab itu, konsep diri sebaiknya dikembangkan dari usia dini salah satunya melalui proses pembelajaran. Dimulai dari pengalaman diri serta interaksi dengan peserta didik lainnya, di mana setiap bagian dari proses harus seimbang sehingga tercipta peserta didik dengan konsep diri yang baik atau sehat. Konsep diri peserta didik bersifat dinamis, yang berarti hal ini dapat berubah sewaktu-waktu. Seseorang yang mengkonsepkan dirinya tinggi biasanya mempunyai pemahaman yang lebih baik akan kemampuan serta kompetensi yang ia miliki, memiliki pandangan diri serta rasa percaya diri yang baik, sehingga memiliki dampak pada aktivitas belajar yang ia sebagai seorang peserta didik (Hartuti, 2015).

Selain mengajar, guru juga memiliki tugas lainnya yaitu membangkitkan rasa keinginan tahu peserta didik agar selalu belajar serta menggali ilmu (Kompasiana.com, 2014). Untuk membangkitkan hal tersebut, guru harus memberikan motivasi kepada peserta didiknya. Dalam pembelajaran, untuk memahami suatu konsep materi yang diajarkan, peserta didik 
harus memiliki motivasi belajar yang baik untuk memperoleh hasil yang baik baik pula (Shidik, 2020). Selain dari motivasi belajar, motivasi berprestasi juga memiliki peran yang cukup penting dalam pembelajaran. Hal ini seperti yang dikemukakan oleh (Rosa, 2015), peserta didik yang memiliki konsep diri tinggi bisanya akan memiliki kepercayaan diri dalam menggali potensi yang ada dalam diri peserta didik tersebut sehingga dapat berpengaruh pada perolehan prestasi yang tinggi. Dengan memberikan motivasi berprestasi kepada peserta didiknya, guru dapat mengangkat semangat peserta didik untuk memperoleh hasil yang baik dan peserta didik secara tidak langsung akan merasakan bahwa mereka mendapat dukungan penuh dari guru untuk berprestasi. Selain itu dengan motivasi yang positif pula, peserta didik akan merasa lebih percaya diri dan dapat membentuk konsep dirinya menjadi lebih baik.

Semakin tinggi konsep diri dan motivasi berprestasi peserta didik, maka hasil belajarnya akan semakin tinggi, begitupun sebaliknya (Cresli, 2019). Hasil penelitian ini juga senada dengan hasil penelitian dari (Qalsum et al., 2015) bahwa ada korelasi yang kuat antara motivasi berprestasi serta konsep diri terhadap hasil belajar peserta didik. Hal ini menandakan bahwa kosep diri dan motivasi berprestasi merupakan salah satu bagian penting dalam kegiatan pembelajaran. Sehingga bisa dikatakan bahwa konsep diri serta motivasi berprestasi sangat membantu bagi peserta didik dalam menerima, menyerap dan memahami pelajaran fisika yang dipelajari.

Oleh karena itu, dengan hasil penelitian ini, diharapkan guru-guru kedepannya dapat membantu peserta didiknya dalam membentuk konsep dirinya agar lebih baik dan selalu memberikan motivasi untuk berprestasi bagi mereka. Dengan diterapkannya hal ini, apa yang menjadi tujuan dalam pembelajaran dapat tercapai secara maksimal atau sesuai dengan harapan.

Peserta didik yang memiliki motivasi berprestasi tinggi, biasanya akan merasa tertantang untuk menyelesaikan tugas-tugas yang diberikan dan biasanya akan lebih aktif di kelas daripada peserta didik yang motivasi berprestasinya rendah. Hal ini sesuai dengan yang diungkapkan oleh Suprapto (2015) bahwa "peserta didik yang memiliki motivasi untuk berprestasi lebih tinggi akan berusaha membedakan dirinya dengan peserta didik yang lain yang tidak memilikinya, di mana peserta didik tersebut akan merasa memiliki tantangan dalam hal menyelesaikan semua tugas tepat sesuai waktu yang diberikan serta berusaha dalam menemukan tawaran solusi untuk setiap persoalan pembelajaran, dan sebaliknya pada diri peserta didik yang memiliki motivasi berprestasi kurang, yang terjadi yaitu menjurus ke arah lebih lambat dan kurang bersemangat untuk menyelesaikan tugastugasnya".

Selain konsep diri serta motivasi dalam berprestasi, ada banyak lagi faktor-faktor yang mempengaruhi hasil belajar seperti faktor eksternal maupun faktor eksternal peserta didik. Dalam penelitian (Sutrisno \& Siswanto, 2016), beberapa hal yang mempengaruhi hasil belajar antara lain: persepsi penguasaan metode mengajar guru, motivasi belajar peserta didik, persepsi media pembelajaran, dan penguasaan metode mengajar praktik guru. Selain itu berdasarkan penelitian-penelitian yang telah terdahulu, ada hal-hal lain yang mempengaruhi hasil belajar peserta didik seperti kondisi peserta didik saat belajar, kepribadian, minat, gaya belajar dan masih banyak hal lagi yang memungkinkan dapat mempengaruhi hasil belajar peserta didik.

Berdasarkan hasil penelitian ini juga dapat diketahui bahwa konsep diri serta motivasi berprestasi menjadi salah satu hal yang penting dalam proses belajar mengajar. Dari hasil penelitian ini diharapkan bagi guru-guru selain memberi pengajaran bagi peserta didik selama proses belajar mengajar, guru juga harus membantu peserta didik dalam membentuk karakter serta memberikan motivasi-motivasi yang dapat meningkatkan keinginan peserta didik dalam berprestasi. Selain itu, orang tua dari peserta didik juga harus selalu mengontrol kegiatan belajar dari peserta didik dalam hal ini anak yang bersangkutan dan selalu memberikan dorongan dan keyakikan pada diri peserta didik tersebut bahwa dengan belajar perserta didik tersebut akan memperoleh hal yang lebih baik. Sedangkan untuk peserta didik sendiri baiknya selalu berprasangka atau menggambarkan 
dirinya dengan sebaik mungkin serta selalu memotivasi diri sendiri melalui mengatur pola belajar menjadi lebih baik, membuat target dalam untuk mencapai prestasi tertentu dan selalu konsisten dengan target prestasi yang ingin dicapai. Dengan melakukan hal ini, guru sudah melakukan salah satu upaya dalam mendorong meningkatnya hasil belajar peserta didik. Motivasi dalam berprestasi memiliki pengaruh yang positif atas hasil balajar peserta didik (Pertiwi \& Shidik, 2020).

Konsep diri memiliki peran dalam diri peserta didik, di mana dengan memahami diri sendiri dan mengkonsepkan diri dengan baik mereka akan mampu membayangkan bagaimana hasil yang akan diperoleh ketika melakukan hal-hal tertentu dalam kegiatan pembelajaran, misalnya ketika dalam kegiatan pembelajaran mereka aktif didalammnya dan termotivasi untuk memperoleh hasil yang baik, maka hasil yang baik akan didapatkan oleh peserta didik. Setiap guru harus bisa membangunkan motivasi peserta didik agar memperoleh hasil belajar yang maksimal demi tercapainya tujuan yang ingin dicapai dalam setiap proses belajar mengajar (Idzhar, 2016).

Menjadi pembimbing sebagai salah satu peran dari guru baiknya lebih diutamakan, sebab kehadiran seorang guru dalam lingkungan sekolah yaitu agar membimbing peserta didik menjadi manusia yang dewasa dengan susila yang baik, berbudi pekerti luhur, berakhlak mulia, dan terampil (Darmadi, 2016). Dengan adanya guru sebagai pendamping bagi peserta didik, diharapkan peserta didik dapat membentuk konsep dirinya dengan baik. Selain itu guru juga memiliki peran sebagai motivator dalam proses pembelajar. Menumbuhkan motivasi berprestasi peserta didik dalam proses belajar mengajar merupakan salah satu dari teknik untuk mengembangkan kemampuan serta keinginan belajar dalam diri peserta didik. Dengan menjadi motivator, guru akan mampu memberi gambaran-gambaran yang menarik bagi peserta didik dalam belajar sehingga mampu menumbuhkan motivasi berprestasi dalam diri peserta didiknya.

Kegiatan pembelajaran yang dilakukan setiap harinya akan lebih efektif lagi jika guru melakukan upaya lainnya selain berbagi ilmu dan menjelaskan materi. Dalam kurikulum 2013 ini, peserta didik tidak hanya dinilai dari aspek intelegensinya (kognitif) saja melainkan ada aspek psikomotor dan afeksinya. Sehingga guru-guru juga perlu berkreasi dalam melakukan pembelajaran dan pengarahan kepada peserta didiknya. Guru dalam mendidik peserta didiknya, baiknya dengan membantu peserta didiknya dalam mengkonsepkan diri mereka dengan baik. Andinny (2015) mengemukakan bahwa konsep diri mempunyai dampak yang positif dalam peningkatan hasil belajar. Sejalan dengan pendapat sebelumnya, Dwija (2008) melalui upaya meningkatkan konsep diri serta motivasi berprestasi maka hasil belajar dapat ditingkatkan pula. Ketika peserta didik memiliki konsep diri yang baik terhadap dirinya sendiri, maka ia akan termotivasi dalam mencapai prestasi yang lebih baik sehingga hasil belajar yang diperoleh nantinya akan baik pula.

\section{PENUTUP}

\section{Simpulan}

Simpulan yang diperoleh dari penelitian ini adalah:

a. konsep diri memiliki pengaruh yang signifikan atas hasil belajar peserta didik.

b. motivasi berprestasi memiliki pengaruh yang signifikan berkenaan dengan hasil belajar fisika peserta didik.

c. Konsep diri serta motivasi berprestasi berpengaruh signifikan berkenaan dengan hasil belajar fisika peserta didik.

d. Guru memiliki peran penting sebagai motivator dan pendamping peserta didik dalam kegiatan belajar mengajar.

\section{Rekomendasi}

Beradasarkan hasil penelitian ini, diharapkan:

a. Bagi guru-guru untuk menjadi referensi agar tidak lupa membantu peserta didik untuk membentuk konsep diri yang tinggi dan baik pada diri peserta didik sendiri. 
b. Agar dalam setiap proses belajar mengajar guru-guru tidak lupa dengan perannya sebagai motivator kepada peserta didik, salah satunya memotivasi peseta didik untuk berprestasi disetiap pelajaran di sekolah maupun di luar sekolah.

c. Bagi peserta didik agar tidak lupa memotivasi diri sendiri untuk berprestasi dan membentuk konsep diri yang baik pada dirinya dengan cara memberikan sugensti pada diri sendiri, mengubah kebiasaan belajar dan memilih cara belajar yang sesuai dengan diri sendiri.

d. Menjadi salah satu referensi bagi peneliti selanjutnya dan dapat dikembangkan lagi untuk menlusuri faktor lainnya yang mempengaruhi hasil belajar fisika peserta didik. 


\section{DAFTAR PUSTAKA}

Anderson, L.W. \& Krathwohl, D.R. (2001). A Taxonomy for Learning, Teaching, and Asessing: A Revision of Bloom's Taxonomy of Educational Objectives. Addison Wesley Longman, Inc.

Andinny, Y. (2015). Pengaruh Konsep Diri dan Berpikir Positif terhadap Prestasi Belajar Matematika Siswa. Formatif: Jurnal Ilmiah Pendidikan MIPA, 3(2), Article 2. https://doi.org/10.30998/formatif.v3i2.119

Asep Budi Hartono. (2015). Pengaruh Konsep Diri Dan Efikasi Diri Terhadap Motivasi Berprestasi (Survei Pada Mahasiswa Pe Fkip Universitas Kuningan). Equilibrium Jurnal Penelitian Pendidikan Dan Ekonomi, 10.

Atkinson, J., \& Feather, N. (1966). A theory of achievement motivation. Wiley and Sons.

Cresli, E. (2019). Pengaruh Motivasi Berprestasi Dan Konsep Diri Terhadap Hasil Belajar Matematika Siswa Kelas VII SMP Frater Makassar. DINAMIS, 16(2, Des), 49-54.

Darmadi, H. (2016). Tugas, Peran, Kompetensi, Dan Tanggung Jawab Menjadi Guru Profesional. Edukasi: Jurnal Pendidikan, 13(2), 161-174. https://doi.org/10.31571/edukasi.v13i2.113

Dimyati, \& Mudjiono. (2013). Belajar dan Pembelajaran. Rineka Cipta.

Dwija, I. W. (2008). Hubungan Antara Konsep Diri, Motivasi Berprestasi dan Perhatian Orang Tua Dengan Hasil Belajar Sosiologi Pada Siswa Kelas II Sekolah Menengah Atas Unggulan di Kota Amlapura. Jurnal Pendidikan Dan Pengajaran, 41(1), Article 1. https://doi.org/10.23887/jppundiksha.v41i1.1977

Esi, Purwaningsih, E., \& Okianna. (2016). Peranan Guru Sebagai Fasilitator Dan Motivator Dalam Meningkatkan Hasil Belajar Di Kelas XI SMK. Jurnal Pendidikan Dan Pembelajaran Khatulistiwa, 5(10), Article 10. https://jurnal.untan.ac.id/index.php/jpdpb/article/view/17132

Faturrahman. (2016). Pengaruh Konsep diri, Perhatian Orang Tua dan Motivasi Berprestasi terhadap Hasil Belajar Fisika Peserta didik Kelas XI SMA Negeri Di Kabupaten Dompu. Universitas Negeri Makassar.

Ghozali, Imam. (2016). Aplikasi Analisis Multivariete Dengan Program IBM SPSS. Badan Penerbit Universitas Diponegoro.

Hartuti, P. M. (2015). Peran Konsep Diri, Minat dan Kebiasaan Belajar Peserta Didik terhadap Prestasi Belajar Fisika. Formatif: Jurnal IImiah Pendidikan MIPA, 5(2). https://doi.org/10.30998/formatif.v5i2.329

Herlina, H. (2016). Pengaruh Model Problem Based Learning Dan Motivasi Berprestasi Terhadap Hasil Belajar Siswa Pada Mata Pelajaran Biologi Di Kelas Xi Ipa Man 2 Model Palu. JSTT, 5(1), Article 1. http://jurnal.untad.ac.id/jurnal/index.php/JSTT/article/view/6956

Hilgard, Ernest. (1983). Introduction to psychology. Harcoust B. Javanovic.

Idzhar, A. (2016). Peranan Guru Dalam Meningkatkan Motivasi Belajar Siswa. Jurnal Office, 2(2), 221-228. https://doi.org/10.26858/jo.v2i2.2956

Kompasiana.com. (2014, December 4). Guru Sebagai Motivator. KOMPASIANA. https://www.kompasiana.com/chrysna.com/54f92956a333116e068b4708/guru-sebagai-motivator

Manizar, E. (2015). PERAN GURU SEBAGAI MOTIVATOR DALAM BELAJAR. Tadrib, 1(2), 204-222.

Martianah, Sri Mulyani. (1984). Motif Sosial Remaja Jawa dan Keturunan Cina Suatu Studi Perbandingan. Gadjah Mada Press.

McClelland, D.C. (1987). Human Motivation. The Press Syndicate of The University of Chambridge. 
Muhammad Awal Nur. (2016). Pengaruh Perhatian Orang Tua, Konsep Diri, Persepsi Tentang Matematika Terhadap Hasil Belajar Matematika Melalui Motivasi Belajar Siswa Kelas Viii Smp Negeri Di Kecamatan Ujung Loe Kabupaten Bulukumba. 2(2).

Muhammad Sudia, \& Muliani Majja. (2016). Pengaruh Motivasi Berprestasi Melalui Kombinasi Model Pembelajaran Kooperatif Terhadap Hasil Belajar Matematika (Studi Eksperimen Pada siswa Kelas VII SMP Negeri 13 Kendari). Jurnal Pendidikan Matematika, 7(1).

Nida, F. L. K. (2014). Membangun Konsep Diri Bagi Anak Berkebutuhan Khusus. 2(1), 20.

Nur, A. S. , \& Massang, B. (2016). Pengaruh Pola Asuh Orang Tua, Konsep Diri, Dan Motivasi Berprestasi Terhadap Prestasi Belajar Matematika Siswa Kelas Ix Smp Negeri Di Kota Merauke. Suska Journal of Mathematics Education, 2(2), 89. https://doi.org/10.24014/sjme.v2i2.2067

Nur Alamsyah. (2016). Pengaruh Konsep Diri terhadap Prestasi Belajar Matematika Siswa SMAN 102 Jakarta. Jurnal SAP, 1(2). https://doi.org/10.30998/sap.v1i2.1022

Pertiwi, P., \& Shidik, M. A. (2020). Hubungan antara Motivasi Berprestasi dengan Hasil Belajar Fisika Peserta Didik. Sainsmat: Jurnal Ilmiah Ilmu Pengetahuan Alam, 9(2), 136-143. https://doi.org/10.35580/sainsmat92153822020

Purwanto. (2009). Evaluasi Hasil Belajar. Yogyakarta: Pustaka Pelajar.

Qalsum, U., Nurhayati, N., \& Yani, A. (2015). Hubungan Antara Konsep Diri Dan Motivasi Berprestasi Dengan Hasil Belajar Fisika Peserta Didik Sma Di Kota Makassar. Jurnal Sains Dan Pendidikan Fisika, 11(2), $132-140$

Rehanja, M. (2017). Pengaruh Konsep Diri Akademis Terhadap Hasil Belajar Siswa Pada Mata Pelajaran Ekonomi. Jurnal Pendidikan Dan Pembelajaran Khatulistiwa, 6(9), Article 9. https://jurnal.untan.ac.id/index.php/jpdpb/article/view/21680

Rosa, N. M. (2015). Pengaruh Sikap Pada Mata Pelajaran Kimia dan Konsep Diri terhadap Prestasi Belajar Kimia. Formatif: Jurnal IImiah Pendidikan MIPA, 2(3), Article 3. https://doi.org/10.30998/formatif.v2i3.104

Sahidin, L. (2013). Pengaruh Motivasi Berprestasi dan Persepsi Siswa Tentang Cara Guru Mengajar Terhadap Hasil Belajar Matematika. JURNAL PENDIDIKAN MATEMATIKA, 4(2).

Sari, A. N. S., \& Taman, A. (2013). Pengaruh Motivasi Berprestasi Dan Persepsi Siswa Tentang Metode Mengajar Guru Terhadap Prestasi Belajar Siswa Smk Negeri 1 Pengasih. Jurnal Pendidikan Akuntansi Indonesia, 11(1), Article 1. https://doi.org/10.21831/jpai.v11i1.1683

Shidik, M. A. (2020). Hubungan Antara Motivasi Belajar Dengan Pemahaman Konsep Fisika Peserta Didik MAN Baraka. Jurnal Kumparan Fisika, 3(2 Agustus), 91-98. https://doi.org/10.33369/jkf.3.2.91-98

Slameto. (2010). Belajar dan Faktor-faktor yang Mempengaruhinya. PT. Rineka Cipta.

Subaryana, S. (2015). KONSEP DIRI DAN PRESTASI BELAJAR. Dinamika Jurnal Ilmiah Pendidikan Dasar, 7(2).

Sudjana, Nana. (2009). Penilaian Hasil Proses Belajar Mengajar. PT Remaja Rosdakarya.

Sugiyono. (2015). Metode Penelitian Kombinasi (Mixed Methods). Alfbeta.

Suprapto, E. (2015). Pengaruh Model Pembelajaran Kontekstual, Pembelajaran Langsung Dan Motivasi Berprestasi Terhadap Hasil Belajar Kognitif. INVOTEC, 11(1), Article 1. https://doi.org/10.17509/invotec.v11i1.4836 
Suryabrata, S. (2002). Psikologi Pendidikan. PT. Grafindo Perkasa Rajawali.

Sutrisno, V. L. P., \& Siswanto, B. T. (2016). Faktor-faktor yang mempengaruhi hasil belajar siswa pada pembelajaran praktik kelistrikan otomotif SMK di Kota Yogyakarta. Jurnal Pendidikan Vokasi, 6(1), 111-120. https://doi.org/10.21831/jpv.v6i1.8118

Tiorenna, S. (2015). Pengaruh Konsep Diri dan Motivasi Berprestasi terhadap Hasil Belajar Matematika Siswa Kelas X (Survei pada SMK Se-Kecamatan Ciracas). Formatif: Jurnal IImiah Pendidikan MIPA, 1(2). https://doi.org/10.30998/formatif.vli2.66

Trisnowali, A. (2017). Pengaruh Motivasi Berprestasi, Minat Belajar Matematika, Dan Sikap Belajar Matematika Terhadap Hasil Belajar Matematika Pada Siswa Sman 2 Watampone. MaPan : Jurnal Matematika dan Pembelajaran, 5(2), 259-278. https://doi.org/10.24252/mapan.v5n2a8

Uno, Hamzah B. (2012). Model Pembelajaran Menciptakan Proses Belajar Mengajar yang Kreatif dan Efektif. Bumi Aksara.

Weiten, W, \& Lloyd, M.A. (2006). Psychology Applied Modern Life: Adjustment In The 21st Century (8th ed.). Thomson Higher Education.

Winkel, W.S. (2014). Psikologi Pengajaran. Sketsa.

Wiyani, T. E. K. (2017). Pengaruh Konsep Diri, Kemandirian, Motivasi Dan Lingkungan Belajar Terhadap Prestasi Belajar Ekonomi Siswa Kelas Xi Ips Sma Negeri Di Kabupaten Gresik. JURNAL EKONOMI PENDIDIKAN DAN KEWIRAUSAHAAN, 1(2), 130-139. https://doi.org/10.26740/jepk.v1n2.p130-139

Yapono, F. (2013). Konsep-Diri, Kecerdasan Emosi Dan Efikasi-Diri. Persona:Jurnal Psikologi Indonesia, 2(3). https://doi.org/10.30996/persona.v2i3.136 